\title{
Agronomic performance of urea in pastilled compositions applied on maize fertilization
}

\author{
Wadson de Menezes Santos ${ }^{1} \odot$, Inácio de Barros $^{2} \odot$, Edson Patto Pacheco ${ }^{3}{ }^{\circ}$, \\ Marcelo Ferreira Fernandes ${ }^{3}\left[0\right.$, Heraldo Namorato de Souza ${ }^{4}[0$

\footnotetext{
1 Universidade Federal Rural do Rio de Janeiro, Seropédica, RJ, Brasil. E-mail: wadson.wms@gmail.com

${ }^{4}$ Petrobras, Rio de Janeiro, RJ, Brasil. E-mail: heraldo.ns@petrobras.com.br
} \\ ${ }^{2}$ Embrapa Gado de Leite, Juiz de Fora, MG, Brasil. E-mail: inacio.barros@embrapa.br \\ ${ }^{3}$ Embrapa Tabuleiros Costeiros, Aracaju, SE, Brasil. E-mail: edson.patto@embrapa.br; marcelo.fernandes@embrapa.br
}

ABSTRACT: Urea pastillation is a technology that allows the composite mixture with other elements like sulfur and zinc. This study aimed to provide recommendations of $\mathrm{N}$ rates, and to assess the agronomic performance of $\mathrm{N}$ fertilizers, including pastille urea and its composition associated with S and Zn, top-dressed on maize. Two experiments were set up in the harvests of 2014 and 2015 in an Acrisol and a Lixisol. The experimental design was the randomized blocks with three replicates in a split-plot arrangement and an additional treatment (no N). In the plot, three $\mathrm{N}$ applications rates were tested (75, 150 and $300 \mathrm{~kg} \mathrm{ha}^{-1}$ ); while in the subplots, seven fertilizers were tested, including conventional and pastilled ones. The greater was the $\mathrm{N}$ rate applied, the higher were the leaf $\mathrm{N}$ content and grain yield of maize. The $\mathrm{S}$ content in the leaves increased with the increasing $\mathrm{S}$ doses applied with the tested fertilizers. Yields with ammonium sulfate were higher than with prilled urea, pastille urea and pastille urea with elemental $S$ in the harvest mean on the Haplic Lixisol. The rate that corresponded to the maximum economic efficiency for

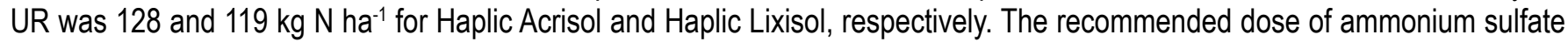
was $119 \mathrm{~kg} \mathrm{ha}^{-1}$, since it provided the greater incomes for both sites.

Key words: nitrogen; nitrogen fertilizers; sulfur

\section{Desempenho agronômico da ureia em composições pastilhadas aplicadas na adubação do milho}

RESUMO: O pastilhamento da ureia é uma tecnologia que permite a complexação com outros elementos como enxofre (S) e zinco (Zn). Este trabalho teve como objetivos a recomendação de doses de nitrogênio (N), e avaliação do desempenho agronômico de $\mathrm{N}$-fertilizantes, incluindo composições pastilhadas de ureia associadas com S e Zn aplicados em cobertura no milho. Dois experimentos foram estabelecidos nas safras 2014 e 2015 em dois Argissolos. 0 delineamento foi em blocos ao acaso com 3 repetições, em esquema de parcelas subdivididas, com tratamento adicional (sem $\mathrm{N}$ ). As parcelas continham as doses de 75, 150 e $300 \mathrm{~kg} \mathrm{ha}^{-1}$ de N, e as subparcelas composta por sete fertilizantes, dentre eles fertilizantes convencionais e pastilhados. $\mathrm{O}$ acréscimo das doses de $\mathrm{N}$ incrementou o teor de $\mathrm{N}$ foliar e a produtividade, e o teor de $\mathrm{S}$ foliar aumentou com as doses de S. O sulfato de amônio proporcionou maior produtividade que a ureia perolada, ureia pastilhada pura, e com $S$ elementar na média das safras no Argissolo Acinzentado. As doses de máxima eficiência econômica para a ureia perolada foram de $128 \mathrm{~kg} \mathrm{ha}^{-1}$ de N no Argissolo Vermelho-Amarelo e $190 \mathrm{~kg} \mathrm{ha}^{-1}$ de N no Argissolo Acinzentado. A dose indicada de sulfato de amônio foi $119 \mathrm{~kg} \mathrm{ha}^{-1}$ de $\mathrm{N}$ para ambos os solos, proporcionando as maiores receitas.

Palavras-chave: nitrogênio; fertilizantes nitrogenados; enxofre 


\section{Introduction}

Maize is one of the most important Brazilian agricultural products, produced in all states of the federation and totaling a production of 73.8 million tons in the 2018/2019 harvest, with a mean yield of $5,854 \mathrm{~kg} \mathrm{ha}^{-1}$ of grains (Conab, 2019).

Historically, the mean Brazilian maize yield is well below the North American one, which was of $11,229 \mathrm{~kg} \mathrm{ha}^{-1}$ of grains in the last harvest (USDA, 2018). Among the several factors that contribute to low yield, the incorrect fertilizers handling, especially the nitrogenous ones, has been highlighted, as this element is one of the most required nutrients, and the most costly, for maize cultivation. Several characteristics that influence the final production of maize are strongly affected by the nutritional status of the plant, in terms of nitrogen (Morais et al., 2015).

$\mathrm{N}$ is the most complex of the nutrients regarding management and recommendation, due to the multiplicity of chemical and biological reactions that control its availability, which, in turn, are heavily influenced by edaphoclimatic conditions (Sainju et al., 2017).

In general, using the $\mathrm{N}$ from mineral fertilizers by maize decreases with the increased dose applied, since these increments increase the losses due to volatilization, leaching and denitrification, especially when urea is used as a source of $\mathrm{N}$ (Cantarella et al., 2018). To minimize losses, $\mathrm{N}$ can be applied partially, or in the case of a single application, it must be carried out in the period of greatest plant demand. In maize, this occurs between stages V4-V6 (second to third week after emergence), as it is at this stage that the productive potential of the crop is determined (Sangoi et al., 2007). Even so, it is estimated that up to $50 \%$ of the total $\mathrm{N}$ applied via fertilization is lost (Zhang et al., 2015).

The high $\mathrm{N}$ demand for maize, associated with the low capacity of unfertilized soils to supply it, the high $\mathrm{N}$ losses in the soil and the high cost of these fertilizers, reinforce the importance of an efficient management of nitrogen fertilizers to obtain yield competitive. Therefore, in order to increase the efficiency of nitrogen fertilization, it is essential to study new sources and dosages of $\mathrm{N}$, which minimize the environmental

A.

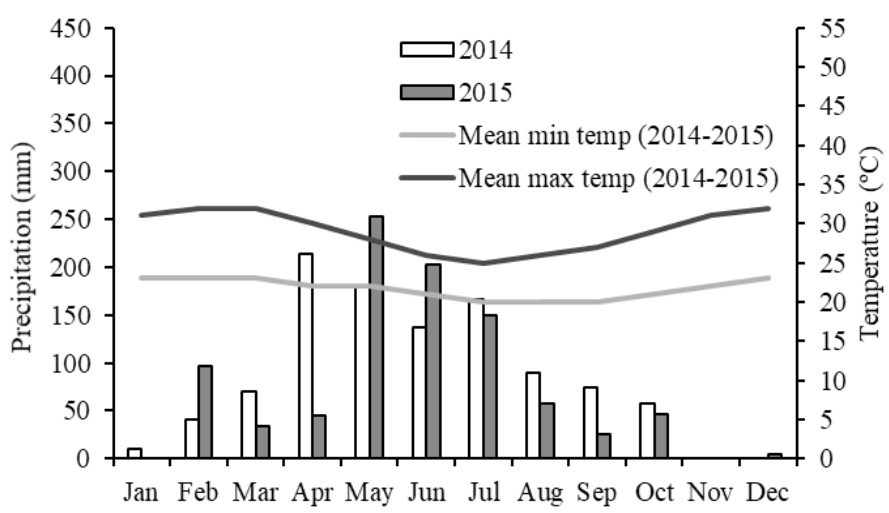

losses, improve agronomic performance and increase the producer income at the same time (Galindo et al., 2016).

Urea is the main $\mathrm{N}$ source in world agriculture (Cantarella et al., 2018) and it can assume several forms such as prills (1.6 $\mathrm{mm})$, granules $(3 \mathrm{~mm})$ and pastilles $(3 \mathrm{~mm})$. The latter is a new technology that allows producing mixed fertilizers, able to gather several nutrients into a single pastille. Adding other elements to the urea and increasing the granule size can reduce ammonia volatilization, thus constituting possible fertilizer production strategies to improve the agronomic performance of crops.

The objective of this study was to evaluate the agronomic performance of conventional nitrogen sources, and urea in pastille tablets, pure or complexed with sulfur (elemental sulfur and ammonium sulfate) and zinc on the top-dressing of maize under conventional planting, as well as obtaining the recommendation of maximum economic efficiency doses for commercial fertilizers in two Acrisols in Northeastern Brazil.

\section{Materials and Methods}

The experiments were conducted in 2014 and 2015 at the Jorge Sobral Experimental Field, located in Nossa Senhora das Dores (SE), in the mid backcountry region of Sergipe ("Sertão Médio"), and at the Experimental Field from Umbaúba (SE), in the Southern region of the same state, both property of Embrapa Coastal Tablelands.

In the Jorge Sobral Experimental Field $\left(10^{\circ} 27^{\prime} \mathrm{S}\right.$ and $37^{\circ} 11^{\prime} \mathrm{O}$, mean altitude of $200 \mathrm{~m}$ ) the soil is a dystrophic "Argissolo Vermelho-Amarelo" (Haplic Acrisol), of clayey texture and undulating relief (Santos et al., 2018). The mean annual temperature is $26^{\circ} \mathrm{C}$ and the mean precipitation is of $1,051 \mathrm{~mm}$ (Figure 1A). In the Umbaúba Experimental Field $\left(11^{\circ} 22^{\prime} 37^{\prime \prime} \mathrm{S}\right.$ and $37^{\circ} 40^{\prime} 26^{\prime \prime} \mathrm{O}$, average altitude of $\left.109 \mathrm{~m}\right)$, the soil is a eutrophic "Argissolo Acinzentado" (Haplic Lixisol) (Santos et al., 2018). The mean annual temperature is $24^{\circ} \mathrm{C}$ and the mean precipitation is of $1,421 \mathrm{~mm}$ (Figure 1B).

Physical and chemical characteristics from the soils of each experimental station were analyzed according to the Manual of Soil Analysis Methods (Embrapa, 1997). Table 1 displays the results found.

B

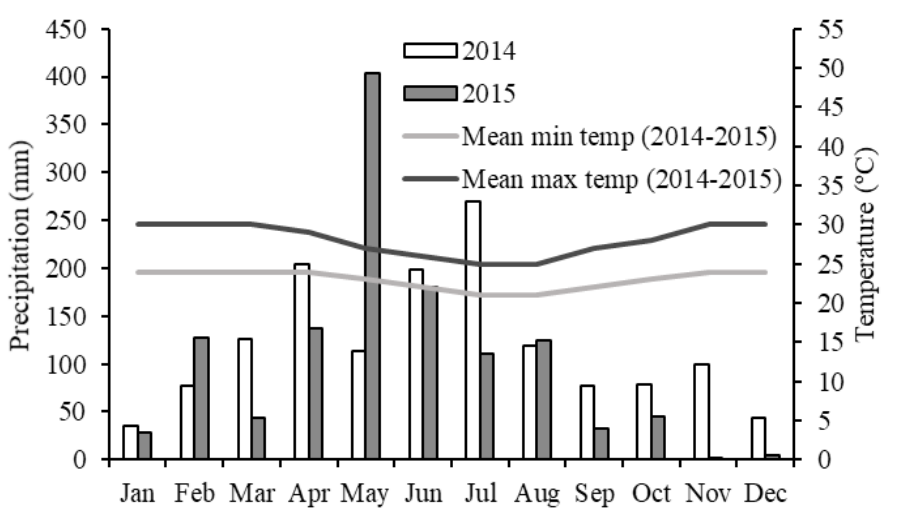

Figure 1. Precipitation, monthly mean maximum and minimum temperatures (2014 and 2015) in (A) Nossa Senhora das Dores (SE), and (B) Umbaúba (SE). 
Table 1. Physical and chemical characteristics of the soil from the experimental area in the depths of 0-20 and $20-40 \mathrm{~cm}$.

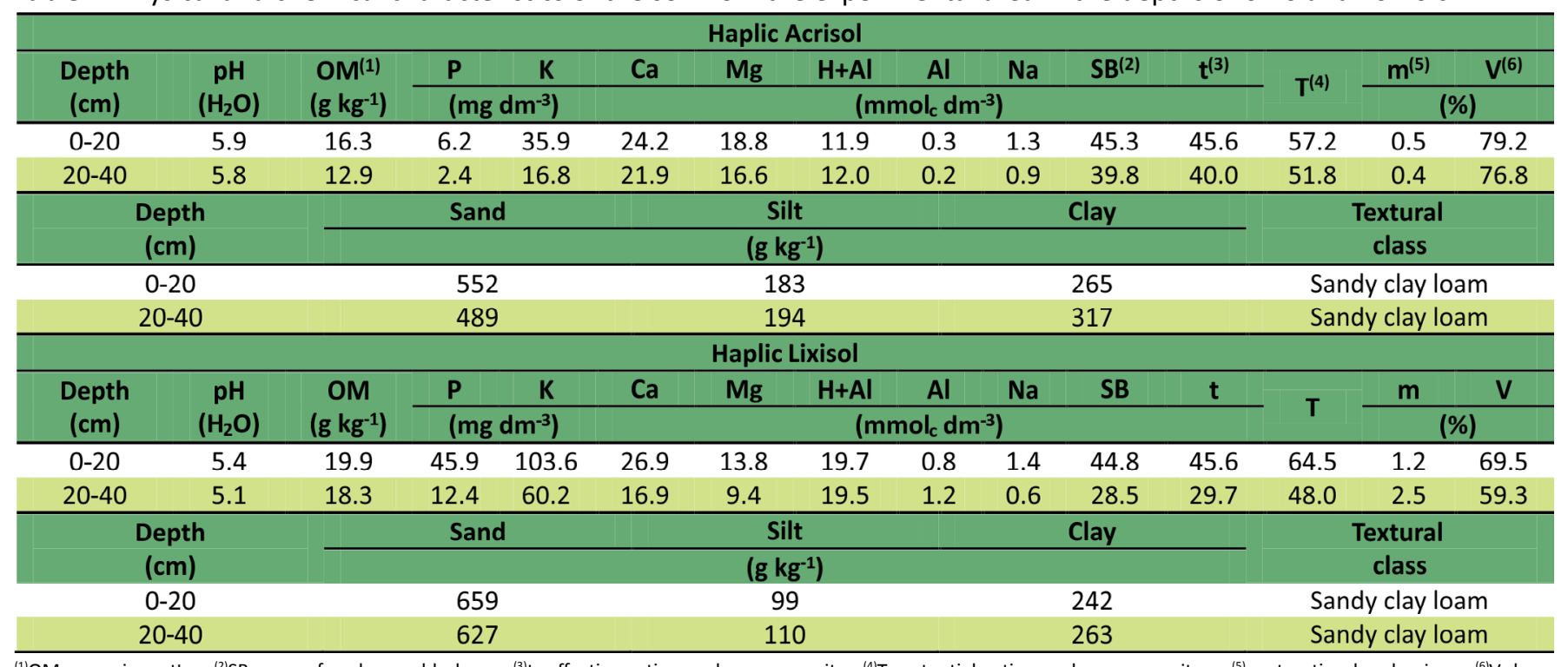

${ }^{(1)} \mathrm{OM}$ : organic matter; ${ }^{(2)} \mathrm{SB}$ : sum of exchangeable bases; ${ }^{\left({ }^{3}\right)} \mathrm{t}$ : effective cation exchange capacity; ${ }^{(4)} \mathrm{T}$ : potential cation exchange capacity; $\mathrm{m}^{(5)}$ : saturation by aluminum ${ }^{\left({ }^{6}\right)} \mathrm{V}$ : base saturation. Analysis methods: $\mathrm{pH}\left(\mathrm{H}_{2} \mathrm{O}-1: 2.5\right) ; \mathrm{OM}$ (colorimetry); $\mathrm{P}, \mathrm{K}$ and $\mathrm{Na}$ (Mehlich 1); $\mathrm{Al}, \mathrm{Ca}$ and $\mathrm{Mg}(\mathrm{KCl} 1 \mathrm{molar}) ; \mathrm{H}+\mathrm{Al}$ (calcium acetate); texture (densimeter method).

The experimental design was the randomized blocks (RCB) with three replicates, in a split-plot scheme and with an additional treatment. The $\mathrm{N}$ doses applied to the plots were 75,150 and $300 \mathrm{~kg} \mathrm{ha}^{-1}$. The subplots were composed by these seven following fertilizers: UP - pure pastilled urea $(44.9 \%$ of $N), U P+S$ - pastilled urea with elemental S ( $44.3 \%$ of $N, 7 \%$ of S), UP+SA - pastilled urea with ammonium sulfate $(37.2 \%$ of $\mathrm{N}$, $7 \%$ of $S), U P+S A+S$ - pastilled urea with ammonium sulfate and elemental $S(40.7 \%$ of $N, 7 \%$ of $S$, from which $50 \%$ is sulfate and $50 \%$ is in the elemental $S$ form), UP+SA+Zn - pastilled urea with ammonium sulfate and sulfate zinc ( $35 \%$ of $N, 7 \%$ of $S, 1 \%$ of $Z n)$, UR - prilled urea ( $45.9 \%$ of $N), S A$ - crystal ammonium sulfate ( $20 \%$ of $\mathrm{N}, 22 \%$ of $\mathrm{S}$ ), and the control (TEST - no $\mathrm{N}$ application - additional treatment), thus totaling 22 treatments, distributed over 72 experimental units.

The subplots had dimensions of $2 \times 5 \mathrm{~m}$, composed of four planting rows, with the two central ones considered as useful area, disregarding $0.5 \mathrm{~m}$ from their ends. Two edges separated the subplots from each other.

As the experiments were mechanically sown, in order to ensure that the control did not receive any $\mathrm{N}$, and that its only external source came from the fertilizers to be tested, with no $\mathrm{N}$ application during the planting fertilization. The treatments were top-dressed in the four central rows of each subplot between stages V4-V5, according to management described by Coelho (2010), who recommends that, in the absence of $\mathrm{N}$ during the sowing, the top-dressing should be performed until the phenological stage from 4 to 5 leaves.

For the implementing the experiments, $1,200 \mathrm{~kg} \mathrm{ha}^{-1}$ of dolomitic limestone were applied, incorporated at a depth of $20 \mathrm{~cm} 60$ days prior to the sowing in 2014, in both soils.

The soil preparation was with a heavy harrowing and two passages of a leveling harrow, with one in the transversal direction and another in the longitudinal direction from the planting rows.
Sowing occurred mechanically in June 2014 and May 2015 in the Haplic Acrisol located in Nossa Senhora das Dores, and in June 2014 and 2015 in the Haplic Lixisol, located in Umbaúba. A Jumil-brand pneumatic fertilizer-sowing machine, model 2670 Pop Exacta Air, with four tracks was employed, pulled by a New Holland tractor, model TM $165-4 \times 4$. The used maize seeds in the sowings were from the simple hybrid AG 7088 VT PRO MAX ${ }^{\circ}$, recommended by the Agricultural Zoning of Climate Risk for the maize crop in the state of Sergipe, harvest of 2018/2019 (Brazil, 2018). The sowing density was of 74,000 seeds per hectare distributed over a spacing between rows of $0.5 \mathrm{~m}$, using a planting speed of $5 \mathrm{~km} \mathrm{~h}^{-1}$. The seeds were deposited at a depth of $5 \mathrm{~cm}$.

Planting fertilizations consisted of applying $43.64 \mathrm{~kg} \mathrm{ha}^{-1}$ of $\mathrm{P}$ in the triple superphosphate form, and $66.41 \mathrm{~kg} \mathrm{ha}^{-1}$ of $\mathrm{K}$ in the potassium chloride form, deposited $5 \mathrm{~cm}$ below and $5 \mathrm{~cm}$ next to the seed. The plants averagely emerged six days after the sowing.

Thirty days after sowing, the herbicide glyphosate was applied at a dose of 1,440 $\mathrm{g}$ of a.i. ha-1 for controlling weed. No additional phytosanitary control was required.

In order to evaluate the contents of nitrogen and sulfur in the leaves, leaf samples were taken when the maize was at the early R1 stage (silking and pollination), averaging 60 days after sowing. Five index leaves (opposite leaf and ear below) were collected per subplot in the two central rows (Gott et al., 2014).

The samples were washed with distilled water and dried in an oven with forced air circulation at 60 ㅇ afterwards, until attaining constant weight. Then, after crushing in a Willyetype stainless-steel knife mill, they were stored in universal pots for subsequent chemical analysis.

The extraction solutions for the $\mathrm{N}$ analyzes were obtained by digestion with hydrogen peroxide and sulfuric acid, and the total $\mathrm{N}$ content were determined by the Kjeldahl method 
(Embrapa, 2009). To determine the S content, digestion via wet granulation (nitric-perchloric) was performed for obtaining the extraction solutions. The $\mathrm{S}$ content were quantified by means of molecular absorption spectrophotometry (Embrapa, 2009).

For estimating grain yield, the useful areas from the subplots were manually harvested. Harvests occurred in November 2014 and October 2015 in the Acrisol, and in November of both years in the Lixisol. Ears were mechanically tracked and weighed after their harvesting to obtain the grain mass and were subsequently corrected to the standard commercial humidity of $13 \%$, by using the greenhouse method to determine the grain moisture (Mapa, 2009). The results were calculated for presentation in $\mathrm{kg}$ of grains ha-1.

The doses of maximum economic efficiency (DMEE) were calculated in function of the mean yield from the harvests of 2014 and 2015 in each soil class, considering the commercial fertilizers prilled urea and ammonium sulfate, since pastilled urea has not yet debuted on the market, and there are no set prices. For this purpose, the first derivate from each regression function of the productive response $\left(\mathrm{kg} \mathrm{ha}^{-1}\right)$ was equaled to the $\mathrm{N}$ doses $\left(\mathrm{kg} \mathrm{ha}^{-1}\right)$, to the relation between the price of nutrient $\left(\mathrm{R} \$ \mathrm{~kg}^{-1}\right)$ and maize $\left(\mathrm{R} \$ \mathrm{~kg}^{-1}\right)$. In order to do this, the price of the $60 \mathrm{~kg}^{-1}$ maize grains sack sold in the state of Sergipe in the 2015 harvest season, consulted in the bulletin of prices paid to producers, was considered in the calculation (Emdagro, 2015). Fertilizer prices were obtained from consultation with Heringer Fertilizers, not taking the freight price into account (Table 2).
The data were analyzed for normality and homogeneity, and then subjected to the analysis of variance and means comparison by the contrast analysis between the control (no N) and the mean of the fertilized treatments doses; and for comparison between the $\mathrm{N}$ sources, the Tukey test was performed at $\mathrm{p} \leq 0.05$. For the $\mathrm{N}$ doses, the Mitscherlich regression model (Equation 1) was employed for the yield variable, while the polynomial regression was for the leaf contents of $\mathrm{N}$ and $\mathrm{S}$.

$$
y=A\left(1-e^{c(x+b)}\right)
$$

In which: $y$ - represents the obtained yield $\left(\mathrm{kg} \mathrm{ha}^{-1}\right) ; \mathrm{A}$ maximum yield ( $\left.\mathrm{kg} \mathrm{ha}^{-1}\right)$; c - nutrient efficacy coefficient; $\mathrm{x}$ quantity of $\mathrm{N}$ applied ( $\mathrm{kg} \mathrm{ha}^{-1}$ ) and $\mathrm{b}$ - quantity of the nutrient supplied by the soil ( $\left.\mathrm{kg} \mathrm{ha}^{-1}\right)$ in an assailable form for plants.

The analyzes of variance, means tests and polynomial regressions were all performed through the Real Statistics supplement for Excel $2016^{\circ}$, while Mitscherlich regressions were estimated by using the least squares method employing the Solver ${ }^{\circledR}$ supplement for Excel $^{\circ}$, in the option of Nonlinear Generalized Reduced Gradation (GRG) solution method.

\section{Results and Discussion}

According to the contrast control vs. fertilized treatments (Table 3), $\mathrm{N}$ content in the leaves was increased by the nitrogen fertilization. The leaf $\mathrm{N}$ content in the unfertilized

Table 2. Prices of the products used to calculate the dosage of the maximum economic efficiency (DMEE) practiced in the state of Sergipe in 2015.

\begin{tabular}{ccc}
\hline Products & Sack prices & Unit price \\
\hline Maize & $\mathrm{R} \$ 35.00-60 \mathrm{~kg}^{-1}$ of grains & $\mathrm{R} \$ 0.58 \mathrm{~kg}^{-1}$ of grains \\
Prilled urea (UR) & $\mathrm{R} \$ 52.00-50 \mathrm{~kg}^{-1}$ & $\mathrm{R} \$ 2.31 \mathrm{~kg}^{-1}$ of $\mathrm{N}$ \\
Crystal ammonium sulfate (SA) & $\mathrm{R} \$ 40.00-50 \mathrm{~kg}^{-1}$ & $\mathrm{R} \$ 4.00 \mathrm{~kg}^{-1}$ of N \\
\hline
\end{tabular}

Table 3. Nitrogen content in the maize index leaf duing the silking and pollination phase, in function of using top-dressed nitrogen fertilizers in the Haplic Acrisol in Nossa Senhora das Dores (SE), and in the Haplic Lixisol in Umbaúba (SE) in the harvests of 2014 and 2015, and their own means.

\begin{tabular}{|c|c|c|c|c|c|c|}
\hline \multirow{2}{*}{$\begin{array}{c}\text { Soils } \\
\text { Harvests }\end{array}$} & \multicolumn{3}{|c|}{ Haplic Acrisol } & \multicolumn{3}{|c|}{ Haplic Lixisol } \\
\hline & 2014 & 2015 & Mean of 2014-2015 & 2014 & 2015 & Mean of 2014-2015 \\
\hline Fertilizers & \multicolumn{6}{|c|}{$\left(\mathrm{g} \mathrm{kg}^{-1}\right)$} \\
\hline UP & $30.2 \mathrm{a}$ & $37.0 \mathrm{a}$ & $33.6 \mathrm{a}$ & $29.5 \mathrm{a}$ & $28.4 \mathrm{a}$ & $28.9 \mathrm{a}$ \\
\hline$U P+S$ & $32.0 \mathrm{a}$ & $35.9 \mathrm{a}$ & $33.9 \mathrm{a}$ & $28.4 \mathrm{a}$ & $28.6 \mathrm{a}$ & $28.5 \mathrm{a}$ \\
\hline UP+SA & $34.2 \mathrm{a}$ & $37.5 \mathrm{a}$ & 35.9 a & $32.5 \mathrm{a}$ & $28.0 \mathrm{a}$ & $30.3 a$ \\
\hline$U P+S A+S$ & $32.0 \mathrm{a}$ & $35.7 a$ & 33.9 a & $29.1 \mathrm{a}$ & $27.9 a$ & $28.5 \mathrm{a}$ \\
\hline SA & $32.6 a$ & 38.7 a & $35.6 a$ & 33.7 a & 30.7 a & $32.2 \mathrm{a}$ \\
\hline TEST vs & $22.0 \mathrm{~b}$ & $26.2 b$ & $24.1 b$ & $20.6 b$ & $19.8 \mathrm{~b}$ & $20.2 b$ \\
\hline FERTILIZED & $32.4 \mathrm{a}$ & $36.5 \mathrm{a}$ & $34.4 \mathrm{a}$ & 30.9 a & $28.7 \mathrm{a}$ & $29.8 \mathrm{a}$ \\
\hline Mean & 31.1 & 35.2 & 33.1 & 29.6 & 27.6 & 28.6 \\
\hline CV (a) \% & 11.2 & 12.2 & 9.4 & 14.6 & 6.8 & 9.9 \\
\hline$C V(b) \%$ & 10.2 & 8.6 & 7.0 & 14.6 & 11.1 & 9.8 \\
\hline
\end{tabular}

Means followed by the same letters do not statistically differ by the contrast analysis and Tukey test at $5 \%$ probability. CV (a) and CV (b) are the coefficients of variation of the plots and subplots, respectively. UP - pure pastilled urea, UP+S - pastilled urea with elemental S; UP+SA - pastilled urea with ammonium sulfate; UP+SA+S - pastilled urea with ammonium sulfate and elemental S; UP+SA+Zn - pastilled urea with ammonium sulfate and zinc sulfate; UR - prilled urea; SA - crystal ammonium sulfate; TEST - control. 
plants was of $24.1 \mathrm{~g} \mathrm{~kg}^{-1}$ in the Acrisol, and $20.2 \mathrm{~g} \mathrm{~kg}^{-1}$ in the Lixisol, and the average of all fertilized treatments was $34.4 \mathrm{~g}$ $\mathrm{kg}^{-1}$ in the Acrisol, and $29.8 \mathrm{~g} \mathrm{~kg}^{-1}$ in the Lixisol, corresponding to an increase $(p<0.05)$ of 42.7 and $47.5 \%$, respectively.

All fertilizers demonstrated good capacity in supplying $\mathrm{N}$ to the plants, since the obtained $\mathrm{N}$ values are between 27 and $35 \mathrm{~g}$ $\mathrm{kg}^{-1}$, a range considered as adequate for the maize crop, according to Cantarella et al. (1996). The leaf $\mathrm{N}$ content found by Maestrelo et al. (2014) in two agricultural crops ranged from 25.1 to 26.9 $\mathrm{g} \mathrm{kg}^{-1}$, with urea and coated urea as $\mathrm{N}$ sources, not reaching the $\mathrm{N}$ leaf sufficiency range. However, the control group had an $\mathrm{N}$ content below the considered as adequate, due to the soils in the experimental areas having low organic matter content, which is the soil main $\mathrm{N}$ source. Most Brazilian soils are acidic and have low natural $\mathrm{N}$ availability, making an exogenous contribution in adequate quantities crucial in ensuring the growth, development and production of the maize crop (Martins et al., 2015).

Comparing only the treatments that received fertilization at different doses, the analysis of variance indicated the doses effect $(p<0.05)$ and the absence of source effects and their interaction with doses for the studied crops (Table 3 and Figure 2). Valderrama et al. (2014) also found no sources effect on the leaf $\mathrm{N}$ content when top-dressing $\mathrm{N}$ in the maize crop, using conventional and coated with polymers ureas, in two consecutive harvests.

Responses of the $\mathrm{N}$ leaf content in function of the topdressed $\mathrm{N}$ doses applied, in the crops-soils combinations (Figure 2 and Figure 2B), significantly fitted to the quadratic regressions, except for the Lixisol during the 2014 harvest, where the fitting was linear.

Mota et al. (2015) observed a linear increase in the leaf $\mathrm{N}$ content, in response to the increased $\mathrm{N}$ doses on maize. Frazão et al. (2014), evaluating the response of the increased $\mathrm{N}$ doses from different sources of nitrogen fertilizers, obtained increased $\mathrm{N}$ leaf with increasing doses following the quadratic polynomial regression.

The leaf $S$ content, in function of the top-dressed $S$ doses on the mean of 2014-2015 harvests, is displayed in Figure 3A for the Haplic Acrisol and in Figure 3B for the Lixisol.
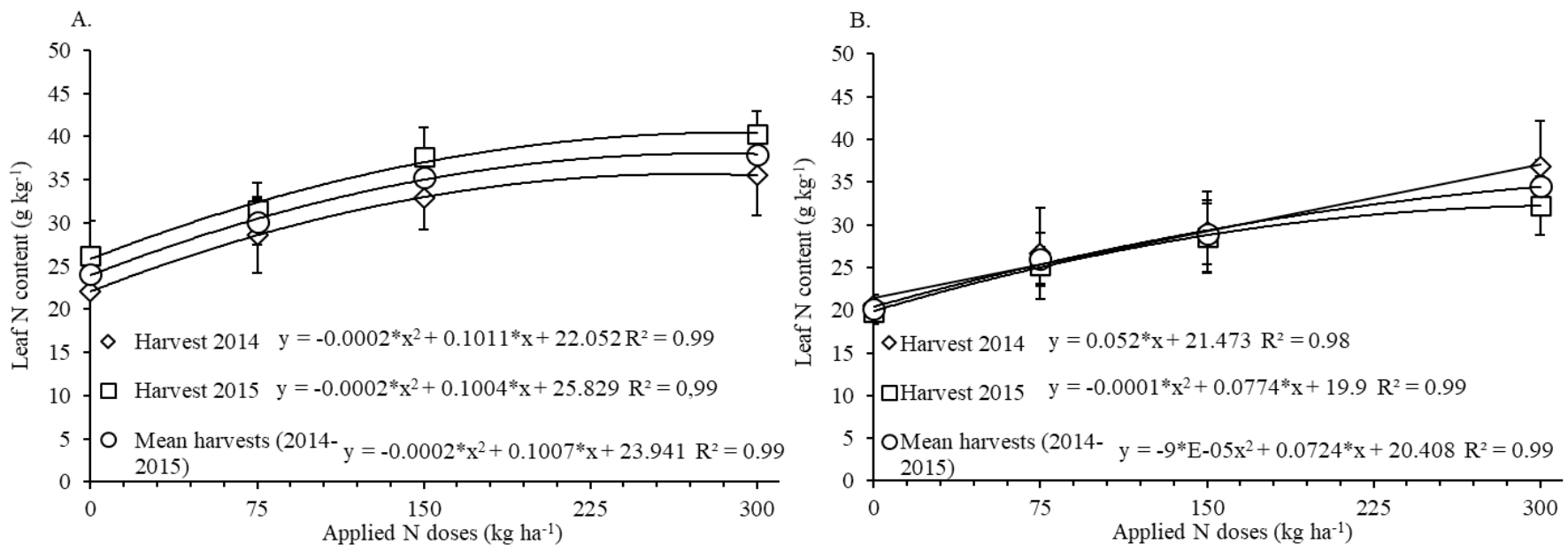

Figure 2. Responses of the leaf $N$ content to the top-dressed $N$ doses in the (A) Haplic Acrisol in Nossa Senhora das Dores (SE), and in the (B) Haplic Lixisol in Umbaúba (SE) in the harvests of 2014 and 2015 and on the mean from the 2014-2015 harvests. * - indicates significance by the $\mathrm{F}$ test at $5 \%$ probability. ${ }^{\mathrm{N}}$ - not significant by the $\mathrm{F}$ test at $5 \%$ probability. Bars indicate the standard deviation.
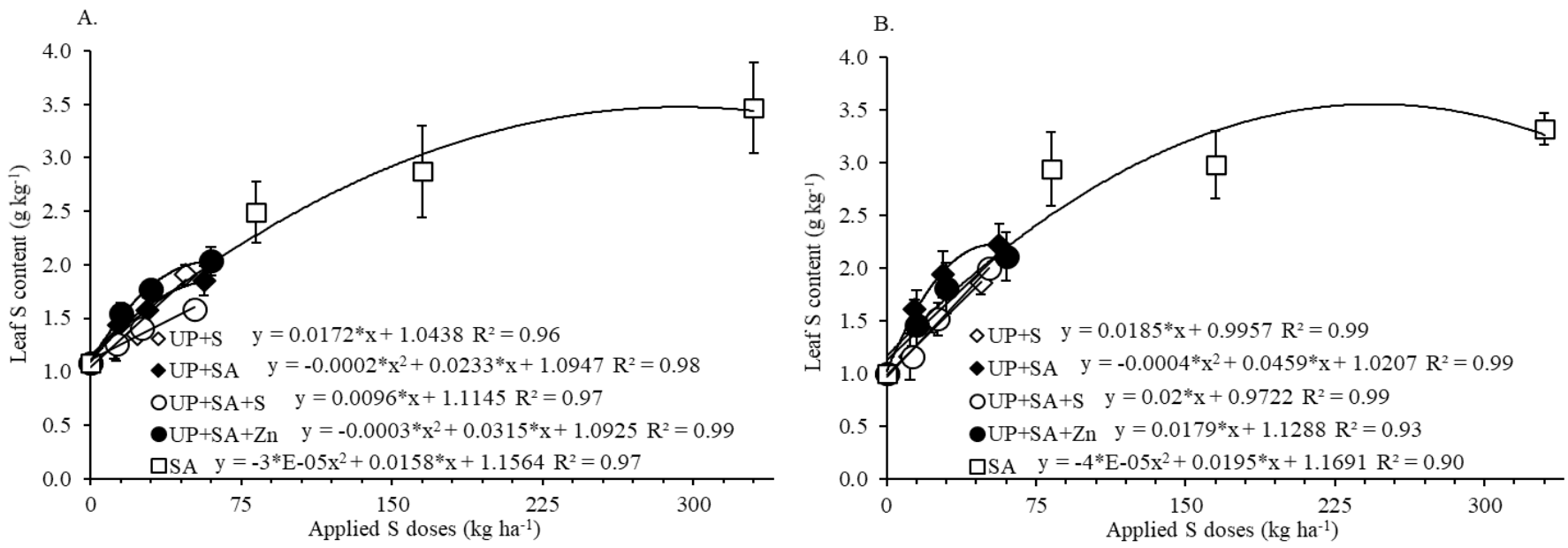

Figure 3. Responses of the leaf S content in function of the top-dressed $S$ in maize on the mean from the $2014-2015$ harvests. (A) in the Haplic Acrisol in Nossa Senhora das Dores (SE), (B) in Haplic Lixisol in Umbaúba (SE). * - indicates significance by the F test at $5 \%$ probability. NS - not significant by the $\mathrm{F}$ test at $5 \%$ probability. Bars indicate the standard deviation. 
There was a significant increase in the $S$ content in the index leaf with increased $S$ doses. SA provided the highest $\mathrm{S}$ content in leaf tissue due to this fertilizer having a high $\mathrm{S}$ content (22\%). N content in this fertilizer is $20 \%$, and to meet a given $\mathrm{N}$ recommendation, $\mathrm{S}$ is applied 1.1 times more than N (Table 4). Galindo et al. (2016) also observed an increased leaf $\mathrm{S}$ content due to the increased $\mathrm{N}$ doses such as urea and Super N.

In general, at the highest $\mathrm{S}$ dose, which corresponds to $300 \mathrm{~kg} \mathrm{ha}^{-1}$ of $\mathrm{N}$, all S-containing sources were able to increase the $S$ content to the range considered as adequate (Table 4), which, according to Cantarella et al. (1996), is between 1.5 and $3.0 \mathrm{~g} \mathrm{~kg}^{-1}$. Among the pastille treatments, UP+SA and $U P+S A+Z n$ at the intermediate doses were able to reach the $S$ sufficiency range, due to more top-dressed $S$ applied by using these sources (Table 4). Despite pastilled fertilizers complexed with sulfur containing the same $\mathrm{S}$ content in their formulations (7\%), $\mathrm{N}$ content are still different. Therefore, different $\mathrm{S}$ doses were applied in order to meet the tested $\mathrm{N}$ doses (75, 150 and $300 \mathrm{~kg} \mathrm{ha}^{-1}$ of N). Mendes et al. (2014) found an increased leaf $\mathrm{S}$ content by applying sulfur-coated urea.

There were significant yield gains in response to the nitrogen fertilization (Table 5). In the Acrisol, no significant difference occurred between the tested $\mathrm{N}$ sources in all harvests and neither in their mean. Goes et al. (2014) using urea, ammonium sulfate and ammonium nitrate as $\mathrm{N}$ sources, also did not find significant differences in the grain yield on the conventional planting system in a Acrisol. However, in Lixisol, the SA treatment stood out by statistically differing from the UP, $U P+S$ and UP+SA+Zn treatments during the 2014 harvest and in the UP, UP+S and UR treatments in the mean of the 20142015 harvests. Thereby, in the mean of harvests, the pastille treatments containing ammonium sulfate did not differ from the SA treatment. Soratto et al. (2010) found that applying N in ammonium sulfate form provided a higher maize yield.

Ammonium sulfate has a higher nutritional efficiency, because, in addition to being a source of sulfur, this fertilizer only suffers losses due to ammonia volatilization in alkaline $\mathrm{pH}$, in this condition the ammonium reacts with hydroxyl forming the ammonia that volatilizes, however this said situation is uncommon under tropical soils (Pan et al., 2016).

In relation to the top-dressed $\mathrm{N}$ doses, the maize response significantly fitted to the Mitscherlich equation (Figure 4 and Figure 4B).

By employing other regression models, Mota et al. (2015) found a linear increase in grain yield in response to the increased top-dressed $\mathrm{N}$ doses, regardless of the used $\mathrm{N}$ source, in two agricultural years. In addition, Gazola et al.

Table 4. Amounts of top-dressed sulfur in maize in function of the tested nitrogen doses, and results of the leaf $S$ content in the maize index leaf in response to the $S$ doses applied to the Haplic Acrisol (PVA) and Haplic Lixisol (PAC).

\begin{tabular}{|c|c|c|c|c|c|c|c|c|c|c|c|c|c|c|c|}
\hline S sources & \multicolumn{3}{|c|}{ UP+S } & \multicolumn{3}{|c|}{ UP+SA } & \multicolumn{3}{|c|}{ UP+SA+S } & \multicolumn{3}{|c|}{$U P+S A+Z n$} & \multicolumn{3}{|c|}{ SA } \\
\hline \multirow[b]{2}{*}{$\begin{array}{l}N^{(1)} \\
\text { Dose }\end{array}$} & \multirow{2}{*}{$\begin{array}{c}S^{(2)} \\
\text { Dose }\end{array}$} & PVA & PAC & \multirow[b]{2}{*}{$\begin{array}{c}\text { S } \\
\text { dose }\end{array}$} & PVA & PAC & \multirow[b]{2}{*}{$\begin{array}{c}\text { S } \\
\text { dose }\end{array}$} & PVA & PAC & \multirow[b]{2}{*}{$\begin{array}{c}\text { S } \\
\text { dose }\end{array}$} & PVA & PAC & \multirow[b]{2}{*}{$\begin{array}{c}\text { S } \\
\text { dose }\end{array}$} & PVA & PAC \\
\hline & & \multicolumn{2}{|c|}{$\begin{array}{l}\text { Leaf } S \\
\text { content }\end{array}$} & & \multicolumn{2}{|c|}{$\begin{array}{c}\text { Leaf S } \\
\text { content }\end{array}$} & & $\begin{array}{l}\text { Le } \\
\text { con }\end{array}$ & & & \multicolumn{2}{|c|}{$\begin{array}{c}\text { Leaf S } \\
\text { content }\end{array}$} & & \multicolumn{2}{|c|}{$\begin{array}{c}\text { Leaf S } \\
\text { content }\end{array}$} \\
\hline (kg N ha-1) & $\left(\mathrm{kg} \mathrm{S} \mathrm{ha-1)}^{-1}\right.$ & \multicolumn{2}{|c|}{$\left(\mathrm{g} \mathrm{kg}^{-1}\right)$} & $\left(\mathrm{kg} \mathrm{S} \mathrm{ha-1)}^{-1}\right.$ & \multicolumn{2}{|c|}{$\left(\mathrm{g} \mathrm{kg}^{-1}\right)$} & $\left(\mathrm{kg} \mathrm{S} \mathrm{ha-1)}^{-1}\right.$ & \multicolumn{2}{|c|}{$\left(\mathrm{g} \mathrm{kg}^{-1}\right)$} & $\left(\mathrm{kg} \mathrm{S} \mathrm{ha-1)}^{-1}\right.$ & \multicolumn{2}{|c|}{$\left(\mathrm{g} \mathrm{kg}^{-1}\right)$} & $\left(\mathrm{kg} \mathrm{S} \mathrm{ha}^{-1}\right)$ & \multicolumn{2}{|c|}{$\left(\mathrm{g} \mathrm{kg}^{-1}\right)$} \\
\hline 75 & 11.9 & 1.3 & 1.2 & 14.1 & 1.4 & 1.6 & 12.9 & 1.3 & 1.2 & 15.0 & 1.5 & 1.5 & 82.5 & 2.5 & 2.9 \\
\hline 150 & 23.7 & 1.3 & 1.5 & 28.2 & 1.6 & 1.9 & 25.8 & 1.4 & 1. & 30.0 & 1.8 & 1.8 & 165.0 & 2.9 & 3.0 \\
\hline 300 & 47.4 & 1.9 & 1.9 & 56.5 & 1.9 & 2.2 & 51.6 & 1.6 & 2.0 & 60.0 & 2.0 & 2.1 & 330.0 & 3.5 & 3.3 \\
\hline
\end{tabular}

${ }^{(1)} \mathrm{N}$ dose: dose of applied nitrogen; ${ }^{(2)} \mathrm{S}$ dose: dose of applied sulfur.

UP+S - pastilled urea with elemental S, UP+SA - pastilled urea with ammonium sulfate, UP+SA+S - pastilled urea with ammonium sulfate and elemental $S$, UP+SA+Zn - pastilled urea with ammonium sulfate and zinc sulfate, SA - crystal ammonium sulfate.

Table 5. Maize yield by top-dressing nitrogen fertilizers under a conventional planting system in Haplic Acrisol in Nossa Senhora das Dores (SE), and in Haplic Lixisol in Umbaúba (SE) in the harvests of 2014 and 2015 and the mean of 2014-2015 harvest.

\begin{tabular}{|c|c|c|c|c|c|c|}
\hline \multirow{2}{*}{$\begin{array}{c}\text { Soils } \\
\text { Harvests } \\
\end{array}$} & \multicolumn{3}{|c|}{ Haplic Acrisol } & \multicolumn{3}{|c|}{ Haplic Lixisol } \\
\hline & 2014 & 2015 & Mean of 2014-2015 & 2014 & 2015 & Mean of $2014-2015$ \\
\hline Fertilizers & \multicolumn{6}{|c|}{$\left(\mathrm{kg} \mathrm{ha}^{-1}\right)$} \\
\hline UP & $4.132 \mathrm{a}$ & $5.354 \mathrm{a}$ & $4.743 \mathrm{a}$ & $5.033 b$ & $4.565 a$ & $4.799 b$ \\
\hline$U P+S$ & $4.071 \mathrm{a}$ & $5.721 \mathrm{a}$ & $4.896 \mathrm{a}$ & $4.898 \mathrm{~b}$ & $5.071 \mathrm{a}$ & $4.985 b$ \\
\hline UP+SA & $4.995 \mathrm{a}$ & $6.137 \mathrm{a}$ & $5.566 \mathrm{a}$ & $5.363 \mathrm{ab}$ & $5.034 a$ & $5.199 a b$ \\
\hline$U P+S A+S$ & $4.562 \mathrm{a}$ & $5.423 \mathrm{a}$ & 4.993 a & $5.244 a b$ & $4.872 \mathrm{a}$ & $5.058 \mathrm{ab}$ \\
\hline SA & $5.013 \mathrm{a}$ & $6.007 \mathrm{a}$ & $5.510 \mathrm{a}$ & $6.311 \mathrm{a}$ & $5.503 \mathrm{a}$ & 5.907 a \\
\hline TEST vs & $1.829 \mathrm{~b}$ & $2.954 \mathrm{~b}$ & $2.391 \mathrm{~b}$ & $3.327 \mathrm{~b}$ & $2.603 b$ & $2.965 b$ \\
\hline FERTILIZED & $4.581 \mathrm{a}$ & $5.653 a$ & $5.117 \mathrm{a}$ & $5.307 \mathrm{a}$ & $4.982 \mathrm{a}$ & $5.145 \mathrm{a}$ \\
\hline Mean & 4.237 & 5.315 & 4.776 & 5.060 & 4.685 & 4.873 \\
\hline CV (a) \% & 34.2 & 15.8 & 23.2 & 27.6 & 17.7 & 10.7 \\
\hline $\mathrm{CV}(\mathrm{b}) \%$ & 16.6 & 13.4 & 12.1 & 16.2 & 14.7 & 11.6 \\
\hline
\end{tabular}

Means followed by the same letters do not statistically differ by the contrast analysis and Tukey test at $5 \%$ probability. CV (a) and CV (b) are the coefficients of variation of the plots and subplots, respectively. UP - pastilled pure urea, UP+S - pastilled urea with elemental S; UP+SA - urea pasted with ammonium sulfate; UP+SA+S - urea pasted with ammonium sulfate and elemental S; UP+SA+Zn - urea pasted with ammonium sulfate and zinc sulfate; UR - prilled urea; SA - crystal ammonium sulfate; TEST - control. 

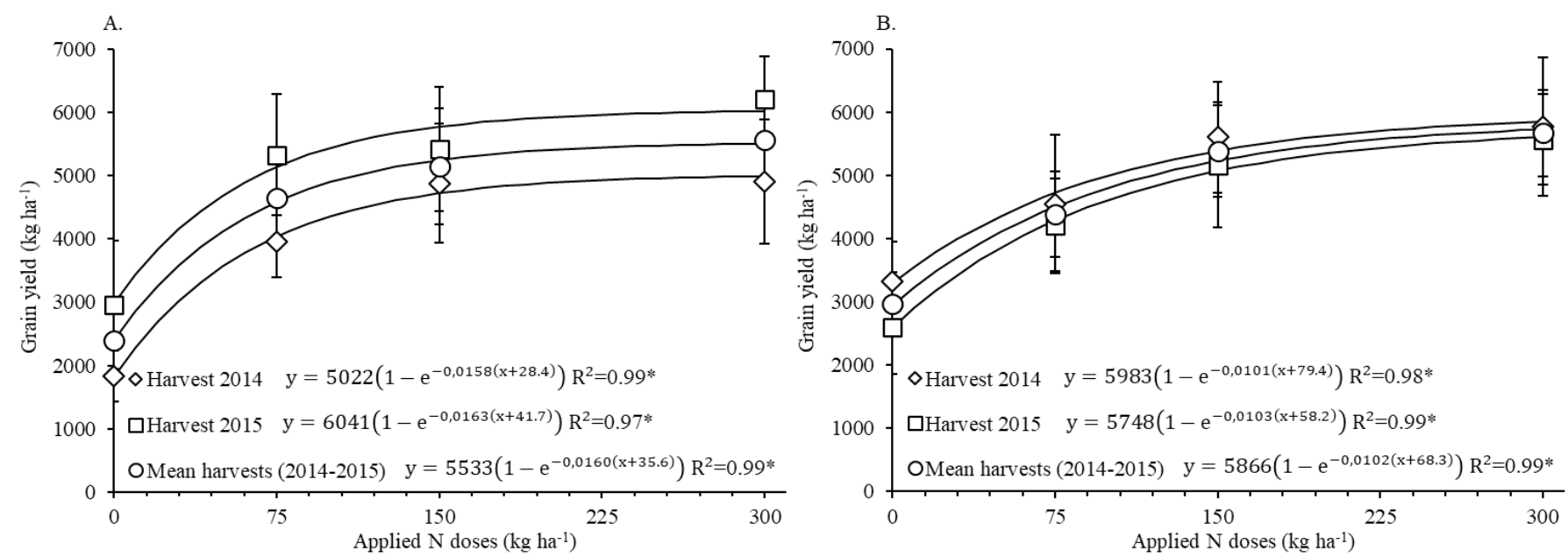

Figure 4. Maize grain yield in function of the top-dressed nitrogen fit by the Mitscherlich equation, in (A) Haplic Acrisol in Nossa Senhora das Dores (SE), and in (B) Haplic Lixisol in Umbaúba (SE), in the harvests of 2014 and 2015 and the mean of the 20142015 harvest. * - indicate that the equation fitting is significant by the $\mathrm{F}$ test at $5 \%$ probability. ${ }^{\text {Ns }}$ - not significant by the $\mathrm{F}$ test at $5 \%$ probability. Bars indicate the standard deviation.

Table 6. Maximum economic efficiency dose (DMEE), grain yield and gross and net income of maize by applying nitrogen fertilizers in the Haplic Acrisol (PVA) in Nossa Senhora das Dores (SE), and in the Haplic Lixisol (PAC) in Umbaúba (SE), on the mean of the 2014-2015 harvest.

\begin{tabular}{|c|c|c|c|c|c|c|}
\hline \multirow{3}{*}{ Soil } & \multicolumn{6}{|c|}{ Haplic Acrisol } \\
\hline & \multirow{2}{*}{ Fertilizers } & \multirow{2}{*}{$\begin{array}{c}\text { DMEE } \\
\left(\mathrm{kg} \mathrm{N} \mathrm{ha}^{-1}\right) \\
\end{array}$} & \multirow{2}{*}{$\begin{array}{c}\text { Yield } \\
(\text { kg grains ha-1) } \\
\end{array}$} & Gross income & Cost with fertilizer & Net income \\
\hline & & & & \multicolumn{3}{|c|}{$\left(\mathrm{R} \$ \mathrm{ha}^{-1}\right)$} \\
\hline \multirow{2}{*}{ PVA } & UR & 128 & 5.078 & 2.945 .24 & 295.68 & 2.649 .56 \\
\hline & SA & 119 & 5.506 & 3.193 .48 & 476.00 & 2.717 .48 \\
\hline \multirow{2}{*}{ PAC } & UR & 190 & 5.227 & 3.031 .66 & 438.90 & 2.592 .76 \\
\hline & SA & 119 & 5.889 & 3.415 .62 & 476.00 & 2.939 .62 \\
\hline
\end{tabular}

UR - prilled urea, SA - crystal ammonium sulfate.

(2014) evaluated different sources and doses of $\mathrm{N}$ on the maize crop and obtained an increased grain yield with the increasing doses, following the quadratic model.

When the top-dressed $\mathrm{N}$ doses are increased, the $\mathrm{N}$ content in the leaves is also increased (Figure 2A and Figure 2B), maximizing the photosynthetic process and, consequently, the grain yield (Figure 4A and Figure 4B) (Caires et al., 2016).

Based on the prices practiced in Sergipe in 2015, the doses of maximum economic efficiency, in other words, the $\mathrm{N}$ dose in which the increased income is equal to the cost per unit of the applied nutrient is illustrated in the Table 6 .

In both studied soils, SA was the fertilizer that provided the highest revenues with the DMEE, even though it was the product with the highest cost per $\mathrm{N}$ unit (R\$ 4.00 $\mathrm{kg}^{-1}$ of $\mathrm{N}-$ Table 1). For both the Lixisol and the Acrisol, DMEE for SA was applied with $119 \mathrm{~kg} \mathrm{ha}^{-1}$ of $\mathrm{N}$, enabling a gross income of $R \$ 3,193.48 \mathrm{ha}^{-1}$ in the Acrisol, and of $\mathrm{R} \$ 3,415.62 \mathrm{ha}^{-1}$ in the Lixisol. Silva et al. (2014) attained the DMEE with the application of $70 \mathrm{~kg} \mathrm{ha}^{-1}$ of $\mathrm{N}$, which in turn provided a yield of $7,406 \mathrm{~kg} \mathrm{ha}^{-1}$ of grains, by using ammonium sulfate in two top-dressings, and under irrigation in the summer.

In general, the economic yields in the Lixisol were higher than in the Acrisol. This result is a direct consequence of the significantly higher yield brought by the SA in relation to UR in the Lixisol (Table 5), which provided a greater increased income ( $R \$ 383.96 \mathrm{ha}^{-1}$ ).

The recommended WEEE are close to those found for other soil classes and regions, such as Queiroz et al. (2011), who achieved maximum economic efficiency at a dose of $120 \mathrm{~kg} \mathrm{ha}^{-1}$ of $\mathrm{N}$ in the Cerrado region, having a yield of 7,470 $\mathrm{kg} \mathrm{ha}^{-1}$ of grains, regardless of the used source. Civardi et al. (2011) demonstrated that using $120 \mathrm{~kg} \mathrm{ha}^{-1}$ of $\mathrm{N}$ in urea form, in the Cerrado region on a Quartzipsamment, provided the highest yield, gross revenue and profit when compared to polymer-coated urea.

In the present study, DMEE for UR differed between the studied sites, this probably due to that urea is the $\mathrm{N}$ source that is most susceptible to losses due to volatilization, determined by environmental conditions. With the SA, there was no variation in the DMEE, since this source is not susceptible to volatilization.

\section{Conclusions}

Under the edaphoclimatic conditions of the study, regardless of the used $\mathrm{N}$ source, the content of this nutrient in the maize leaf increases with the increasing applied doses. The same behavior occurs in relation to the leaf $\mathrm{S}$ content and the increasing sulfur top-dressings. 
Cultivated under a conventional system, the maize yield in response to the nitrogen fertilization, applied in a single topdressing dose, follows the model of decreasing increments and can be adequately represented by the Mitscerlich function, both in the Haplic Acrisol and in the Haplic Lixisol.

The urea dose of maximum economic efficiency is $128 \mathrm{~kg}$ $\mathrm{ha}^{-1}$ of $\mathrm{N}$ for the Acrisol, while in Lixisol it is $190 \mathrm{~kg} \mathrm{ha}^{-1}$ of $\mathrm{N}$.

In the Lixisol, ammonium sulfate provides higher yields than prilled urea or pastilled urea, whether it is complexed with S or not.

For both types of soil studied, the ammonium sulfate dose for maximum economic efficiency is $119 \mathrm{~kg} \mathrm{ha}^{-1}$ of $\mathrm{N}$.

\section{Acknowledgements}

Petrobras, for financing the research project; CAPES, for granting the scholarship; and the Embrapa Coastal Tablelands, for the technical-scientific support.

\section{Literature Cited}

Brasil. Ministério da Agricultura, Pecuária e Abastecimento; Secretaria de Política Agrícola. Portaria n. 109, de 11 de julho de 2018. Aprova o Zoneamento Agrícola de Risco Climático para a cultura de milho no estado de Sergipe, ano-safra 2018/2019. Diário Oficial da União, v.155, n. 133, seção 1, p.43-51, 2018. https://apps.agr.br/zoneamento-agricola-2018-2019. 29 Jan. 2019.

Caires, E.F.; Milla, R. Adubação nitrogenada em cobertura para o cultivo de milho com alto potencial produtivo em sistema de plantio direto de longa duração. Bragantia, v.75, n.1, p.87-95, 2016. https://doi.org/10.1590/1678-4499.160.

Cantarella, H.; Otto, R.; Soares, J.R.; Silva, A.G.B. Agronomic efficiency of NBPT as a urease inhibitor: A review. Journal of Advanced Research, v.13, p.19-27, 2018. https://doi.org/10.1016/j. jare.2018.05.008.

Cantarella, H.; Raij, B. van; Camargo, C.E.O. Recomendações de calagem e adubação para o estado de São Paulo. Campinas: Instituto Agronômico de Campinas, 1996. 285p.

Civardi, E.A.; Silveira Neto, N.A.; Ragagnin, V.A.; Godoy, E.R.; Elias, B. Ureia de liberação lenta aplicada superficialmente e ureia comum incorporada ao solo no rendimento do milho. Pesquisa Agropecuária Tropical, v.41, n.1, p.52-59, 2011. https://doi. org/10.5216/pat.v41i1.8146.

Coelho, A.M. Manejo da adubação nitrogenada na cultura do milho. Sete Lagoas: Embrapa Milho e Sorgo, 2010. 11p. (Embrapa Milho e Sorgo. Circular Técnica, 96). http://www.infoteca.cnptia. embrapa.br/infoteca/handle/doc/486122. 10 Mar. 2019.

Companhia Nacional de Abastecimento - Conab. Acompanhamento da safra brasileira de grãos: monitoramento agrícola safra 2018/2019. Brasília: Conab, 2019. v.6, n.12, 126p. https://www. conab.gov.br/info-agro/safras/graos/boletim-da-safra-de-graos/ item/download/28484_9a9ee12328baa359b3708d64e774e 5d8. 02 Jan. 2020.
Empresa Brasileira de Pesquisa Agropecuária - Embrapa. Manual de métodos de análise de solos. 2ª ed. Rio de Janeiro: Embrapa Solos, 1997. 212p.

Empresa Brasileira de Pesquisa Agropecuária - Embrapa. Manual de análises químicas de solos, plantas e fertilizantes. 2.ed. Brasília: Embrapa Informação Tecnológica, 2009. 627p.

Empresa de Desenvolvimento Agropecuário de Sergipe - Emdagro. Preços médios pagos pelos produtores - mensal/2015. http:// www.emdagro.se.gov.br/modules/tinyd0/index.php?id=57. 14 Dez. 2018.

Frazão, J.J.; Silva, Á.R.; Silva, V.L.; Oliveira, V.A.; Corrêa, R.S. Fertilizantes nitrogenados de eficiência aumentada e ureia na cultura do milho. Revista Brasileira de Engenharia Agrícola e Ambiental, v.18, n.12, p.1262-1267, 2014. https://doi.org/10.1590/18071929/agriambi.v18n12p1262-1267.

Galindo, F.S.; Teixeira Filho, M.C.M.; Buzetti, S.; Santini, J.M.K.; Alves, C.J.; Nogueira, L.M.; Ludkiewicz, M.G.Z.; Andreotti, M.; Bellotte, J.L.M. Corn yield and foliar diagnosis affected by nitrogen fertilization and inoculation with Azospirillum brasilense. Revista Brasileira de Ciência do Solo, v.40, e0150364, 2016. https://doi. org/10.1590/18069657rbcs20150364.

Gazola, D.; Zucareli, C.; Silva, R.R.; Fonseca, I.C.B. Aplicação foliar de aminoácidos e adubação nitrogenada de cobertura na cultura do milho safrinha. Revista Brasileira de Engenharia Agrícola e Ambiental, v.18, n.7, p.700-707, 2014. https://doi.org/10.1590/ S1415-43662014000700005.

Goes, R.J.; Rodrigues, R.A.F.; Takasu, A.T.; Arf, O. Fontes e doses de nitrogênio em cobertura para a cultura do milho em espaçamento reduzido. Revista Agrarian, v.7, n.24, p.257-263, 2014. http://ojs. ufgd.edu.br/index.php/agrarian/article/view/2482. 29 Dez. 2018.

Gott, R.M.; Aquino, L.A. de; Carvalho, A.M.X. de; Santos, L.P.D. dos; Nunes, P.H.M.P.; Coelho, B.S. Índices diagnósticos para interpretação de análise foliar do milho. Revista Brasileira de Engenharia Agrícola e Ambiental, v.18, n.11, p.1110-1115, 2014. https://doi.org/10.1590/1807-1929/agriambi.v18n11p1110-1115.

Maestrelo, P.R.; Buzetti, S.; Teixeira Filho, M.C.M.; Garcia, C.M.P.; Rodrigues, M.A.C.; Lino, A.C.M.; Andreotti, M. Aplicação de ureia revestida em cobertura no milho irrigado sob sistema de semeadura direta. Revista Brasileira de Ciências Agrárias, v.9, n.2, p.192-199, 2014. https://doi.org/10.5039/agraria.v9i2a3708.

Martins, M.R.; Jantalia, C.P.; Polidoro, J.C.; Batista, J.N.; Alves, B.J.R.; Boddey, R.M.; Urquiaga, S. Nitrous oxide and ammonia emissions from $\mathrm{N}$ fertilization of maize crop under no-till in a Cerrado soil. Soil and Tillage Research, v.151, p.75-81, 2015. https://doi. org/10.1016/j.still.2015.03.004.

Mendes, M.C.; Walter, A.L.B.; Possato Junior, O.; Rizzardi, D.A.; Schlosser, J.; Szeuczuk, K. Dose de nitrogênio associado a enxofre elementar em cobertura na cultura do milho em plantio direto. Revista Brasileira de Milho e Sorgo, v.13, n.1, p.96-106, 2014. https://doi.org/10.18512/1980-6477/rbms.v13n1p96-106.

Ministério da Agricultura, Pecuária e Abastecimento - Mapa. Regras para análise de sementes. Secretaria de Defesa Agropecuária. Brasília: Mapa/ACS, 2009. 399p. http://www.agricultura.gov. $\mathrm{br} / a s s u n t o s /$ insumos-agropecuarios/arquivos-publicacoesinsumos/2946_regras_analise_sementes.pdf. 02 Jan. 2020. 
Morais, T.P.; Brito, C.H.; Ferreira, A.S.; Luz, J.M.Q. Aspectos morfofisiológicos de plantas de milho e bioquímico do solo em resposta à adubação nitrogenada e à inoculação com Azospirillum brasilense. Revista Ceres, v.62, n.6, p.589-596, 2015. https://doi. org/10.1590/0034-737X201562060012.

Mota, M.R.; Sangoi, L.; Schenatto, D.E.; Giordani, W.; Boniatti, C.M.; Dall'igna, L. Fontes estabilizadas de nitrogênio como alternativa para aumentar o rendimento de grãos e a eficiência de uso do nitrogênio pelo milho. Revista Brasileira de Ciência do Solo. v.39, n.2, p.512-522, 2015. https://doi.org/10.1590/01000683r bcs20140308.

Pan, B.; Lam, S.K.; Mosier, A.; Luo, Y.; Chen, D. Ammonia volatilization from synthetic fertilizers and its mitigation strategies: a global synthesis. Agriculture, Ecosystems \& Environment, v.232, p.283289, 2016. https://doi.org/10.1016/j.agee.2016.08.019.

Queiroz, A.M.; Souza, C.H.E.; Machado, V.J.; Lana, R.M.Q.; Korndorfer, G.H.; Silva, A.A. Avaliação de diferentes fontes e doses de nitrogênio na adubação da cultura do milho (Zea mays L.). Revista Brasileira de Milho e Sorgo, v.10, n.3, p.257-266, 2011. https://doi.org/10.18512/1980-6477/rbms.v10n3p257-266.

Sainju, U. Determination of nitrogen balance in agroecosystems. MethodsX, v.4, p.199-208, 2017. https://doi.org/10.1016/j. mex.2017.06.001.

Sangoi, L.; Ernani, P.R.F. Maize response to nitrogen fertilization timing in two tilages system in a soil with hight organic matter contente. Revista Brasileira de Ciência do Solo, v.31, n.3, p.507-517, 2007. https://doi.org/10.1590/S0100-06832007000300011.
Santos, H.G.; Jacomine, P.K.T.; Anjos, L.H.C.; Oliveira, V.A.; Lumbreras, J.F.; Coelho, M.R.; Almeida, J.A.; Araujo Filho, J.C.; Oliveira, J.B.; Cunha, T.J.F. Sistema brasileiro de classificação de solos. 5.ed. Rio de Janeiro: Embrapa Solos, 2018. 531p.

Silva, G.F.; Oliveira, F.H.T.; Pereira, R.G.; Silva, P.S.L.; Diogenes, T.B.A.; Silva, A.R.C. Doses de nitrogênio e fósforo para produção econômica de milho na Chapada do Apodi, RN. Revista Brasileira de Engenharia Agrícola e Ambiental, v.18, n.12, p.1247-1254, 2014. https://doi.org/10.1590/1807-1929/agriambi.v18n12p1247-1254.

Soratto, R.P.; Pereira, M.; Costa, T.A.M.; Lampert, V.N. Fontes alternativas e doses de nitrogênio no milho safrinha em sucessão à soja. Revista Ciência Agronômica, v.41, n.4, p.511-518, 2010. https://doi.org/10.1590/S1806-66902010000400002.

United States Department of Agriculture - USDA. Crop production (November 2018). Washington: USDA; National Agricultural Statistics Service, 2018. 48p. https://www.nass.usda.gov/ Publications/Todays_Reports/reports/crop1118.pdf. 29 Jan. 2019.

Valderrama, M.; Buzetti, S.; Teixeira Filho, M.C.M.; Benett, C.G.S.; Andreotti, M. Adubação nitrogenada na cultura do milho com ureia revestida por diferentes fontes de polímeros. Semina: Ciências Agrárias, v.35, n.2, p.659-670, 2014. https://doi. org/10.5433/1679-0359.2014v35n2p659.

Zhang, X.; Davidson, E.A.; Mauzerall, D.L.; Searchinger, T.D.; Dumas, P.; Shen, Y. Managing nitrogen for sustainable development. Nature, v.528, n.53, p.51-59, 2015. https://doi.org/10.1038/ nature15743. 